\title{
Antibacterial Effects of Boric Acid Against Aquatic Pathogens
}

\author{
Ecren UZUN YAYLACI \\ Karadeniz Technical University, Surmene Faculty of Marine Science, Trabzon, Turkey
}

\begin{abstract}
Boron is a bioactive trace element generally found in rock, soil, water and air. It is an essential micronutrient for plants besides having beneficial effects on biological functions of human and animal health. Boric acid has antibacterial properties. Thus, the aim of this study was to evaluate the possible bactericidal and bacteriostatic effects of boric acid on the aquatic pathogens: Aeromonas veronii, Photobacterium damselae subsp. damselae, Vibrio anguillarum, Vibrio vulnificus, Vibrio harveyi, Vibrio rotiferianus, Vibrio tubiashii, Vibrio parahaemolyticus, Vibrio furnissii and Vibrio fluvialis. The inhibitory properties of boric acid were detected by agar well diffusion, minimum inhibitory concentration (MIC), and minimum bactericidal concentration (MBC) methods. The results showed that Photobacterium damselae subsp. damselae and Vibrio species were resistant to different concentrations of boric acid. However, boric acid showed an inhibitory effect against Aeromonas veronii at concentrations of 3.09 and $1.54 \mathrm{mg} / \mathrm{ml}$ and zone diameters on the agar were measured as $19.4 \pm 0.5,15.92 \pm 0.6 \mathrm{~mm}$, respectively. The MIC and MBC of boric acid for Aeromonas veronii were found to be effective at a concentration of $1.54 \mathrm{mg} / \mathrm{ml}$. These results suggested that boric acid might serve as a potential antimicrobial agent for Aeromonas veronii in aquaculture.
\end{abstract}

Keywords: Antibacterial, aquatic pathogen, boric acid, MIC and MBC.

\section{Borik Asitin Sucul Patojenler Üzerine Olan Antibakteriyel Etkileri}

*Sorumlu yazar:

Ecren UZUN-YAYLACI

Karadeniz Teknik Üniversitesi, Sürmene

Deniz Bilimleri Fakültesi, Trabzon, Türkiye

凶: ecrenuzun@ktu.edu.tr

\begin{abstract}
Öz: Bor, genellikle kaya, toprak, su ve havada bulunan biyoaktif bir eser elementtir. Borik asidin insan ve hayvan sağlığının biyolojik fonksiyonları üzerinde faydalı etkileri bulunmaktadır. Bitkiler için de vazgeçilmez bir mikro besin olan borik asit antibakteriyel özelliktedir. Bu çalışmanın amacı borik asidin sucul patojenlerden Aeromonas veronii, Photobacterium damselae subsp. damselae, Vibrio anguillarum, Vibrio vulnificus, Vibrio harveyi, Vibrio rotiferianus, Vibrio tubiashii, Vibrio parahaemolyticus, Vibrio furnissii ve Vibrio fluvialis'e karşı bakterisidal ve bakteriostatik etkilerini incelemektir. Bu çalışmada, borik asidin inhibisyon özellikleri, agar kuyusu difüzyonu, minimum inhibisyon konsantrasyonu (MiK) ve minimum bakterisidal konsantrasyonu (MBK) yöntemleri kullanılarak tespit edilmiştir. Sonuçlar, Photobacterium damselae subsp. damselae ve Vibrio türlerinin farklı konsantrasyonlardaki borik aside karş1 dirençli olduğunu göstermiştir. Bununla birlikte, borik asit 3,09 ve $1,54 \mathrm{mg} / \mathrm{ml}$ konsantrasyonlarında Aeromonas veronii' ye karşı inhibitör etki göstermiştir ve agarda sırasıyla $19,4 \pm 0,5 \mathrm{~mm}$ ve 15,92 $\pm 0,6 \mathrm{~mm}$ halka çapları ölçülmüştür. Aeromonas veronii için MIK ve MBK değerleri $1,54 \mathrm{mg} / \mathrm{ml}$ olarak belirlenmiştir. Bu sonuçlar, borik asidin, su ürünleri yetiştiriciliğinde Aeromonas veronii için potansiyel bir antimikrobiyal ajan görevi görebileceğini ileri sürmektedir.
\end{abstract}

Anahtar kelimeler: Antibakteriyel, borik asit, MiK ve MBK, sucul patojen. 


\section{INTRODUCTION}

Aquaculture is the world's fastest-growing food production sector. However, diseases outbreaks causing serious economic losses (Hatha et al., 2005). Antibiotic treatment has been applied for many years against bacterial infections in aquaculture (Done et al., 2015). The extensive use of antibiotics causes the change of microbiota in aquaculture and can led to development of antibiotic resistant bacteria (Akkan \& Çolaker, 2020; Akkan \& Topkaraoğlu, 2019; Balta et al., 2016; Balta \& Dengiz Balta, 2016; 2017; 2019; Balta, 2020; Resende et al., 2012). A novel alternative to antimicrobial therapy, boric acid can be recommended for treatment of bacterial infections.

Boron is a trace element generally found in rock, soil, water, air etc. in different forms such as borates, boric acid, and boric oxide (Samman et al., 1998). It is an essential dietary component for animals in metabolic, nutritional, and physiological processes (Nielsen, 1997). In aquaculture, boron-supplemented feeds have been used in various fish species (Öz et al., 2018; Topal et al., 2016). Öz et al. (2018) reported that adding $0.05 \%$ boron to the feed improves the growth of rainbow trout. However, higher concentrations of boron can be toxic to certain animal (Goldbach et al., 2007). Boron-containing compounds exhibit antibacterial, antifungal, antiparasitic, antiviral and anti-inflammatory activities (Yang et al., 2018). Boric acid has been tested on different bacterial species for antimicrobial activity (Dinca \& Scorei, 2013; Houlsby et al., 1986; Russel \& Diez-Gonzalez, 1998; Y1lmaz, 2012) and has been reported to have antibacterial effects on some aquatic pathogen bacteria including Aeromonas hydrophila, Vibrio anguillarum, Yersinia ruckeri and Lactococcus garvieae (Sayin et al., 2016).

While there are many studies on the antimicrobial effects of boric acid in human and animal pathogens, little has been reported on the use of boric acid as an antimicrobial agent in aquatic pathogens. The objective of the present report was to evaluate whether boric acid can serve as a potential antimicrobial agent for aquatic bacterial pathogen.

\section{MATERIAL AND METHOD}

Bacterial strains and cultivation: The following species of bacteria which are isolated from naturally infected sea bass (Dicentrarchus labrax) were used in the study; Vibrio vulnificus (KF443055), Vibrio harveyi (KF443059), Vibrio rotiferianus (KF443057), Aeromonas veronii (KF443052) and Photobacterium damselae subsp. damselae (KF443044) confirmed previously by Uzun and Ogut (2015); Vibrio anguillarum (MH036330.1), Vibrio tubiashii (KY003125.1), Vibrio parahaemolyticus
(EF684942.1), Vibrio furnissii (MG214325.1) and Vibrio fluvialis (KC208202.1) confirmed previously by Uzun (2019). Bacterial cultures were grown overnight on tryptic soy agar (TSA) $(+1.5 \% \mathrm{NaCl})$ at $24-26{ }^{\circ} \mathrm{C}$ for $24 \mathrm{~h}$. The concentration of bacterial suspensions in tryptic soy broth (TSB) was adjusted by spectrophotometer to an optical density of 0.10 at $625 \mathrm{~nm}$. Equivalent to concentrations of $1-5 \times 10^{8} \mathrm{CFU} / \mathrm{ml}$ based on a $0.5 \mathrm{McF}$ arland standard.

Diffusion test: The agar well diffusion assay with modification after Perez et al. (1990) was carried out to screening the inhibitory activity of boric acid $\left(\mathrm{H}_{3} \mathrm{BO}_{3}, \mathrm{M}=\right.$ $61.83 \mathrm{~g} / \mathrm{mol}$ ). $50 \mu \mathrm{l}$ of bacterial suspensions approximately containing of $1-5 \times 10^{8} \mathrm{CFU} / \mathrm{ml}$ was spread on tryptic soy agar (TSA) $(+1.5 \% \mathrm{NaCl})$ plates. Wells of $5 \mathrm{~mm}$ in diameter were tip-punched in the agar and filled with $40 \mu \mathrm{l}$ $3.09 \mathrm{mg} / \mathrm{ml}, 1.54 \mathrm{mg} / \mathrm{ml}, 0.77 \mathrm{mg} / \mathrm{ml}, 0.38 \mathrm{mg} / \mathrm{ml}$ and 0.19 $\mathrm{mg} / \mathrm{ml}$ of boric acid. Plates were incubated at $24-26^{\circ} \mathrm{C}$ for $24 \mathrm{~h}$, inhibitory zone was measured. All experiments were repeated in triplicate.

MIC Determination: Minimum inhibitory concentration was calculated by standard macro-dilution method. Serial two-fold gradient dilutions of boric acid in concentrations ranging from $3.09 \mathrm{mg} / \mathrm{ml}$ to $0.19 \mathrm{mg} / \mathrm{ml}$ were prepared in TSB. Bacterial suspension adjusted to a McFarland standard 0.5 were added to all tubes and incubated at $24-26^{\circ} \mathrm{C}$ for $24 \mathrm{~h}$. A tube containing only TSB was used as a negative control and only inoculated TSB with no boric acid served as positive control. The experiments were repeated three times and compared to the controls. The MIC is the lowest concentration of boric acid where no visible growth is seen in the tubes.

MBC Determination: After the MIC determination of the boric acid, mixture of $50 \mu \mathrm{l}$ from all the tubes which showed no visible bacterial growth were streaked on (TSA) $(+1.5 \% \mathrm{NaCl})$ plates and incubated at $24-26^{\circ} \mathrm{C}$ for $24 \mathrm{~h}$. The MBC was determined by the lowest concentration that kills $99.9 \%$ of the initial bacterial population.

\section{RESULTS}

Diffusion test: Boron-containing compounds exhibit antibacterial, antifungal, antiparasitic, antiviral and anti-inflammatory activities (Yang et al., 2018). Boric acid has previously been reported to have antibacterial effects on some aquatic pathogens including Aeromonas hydrophila, Vibrio anguillarum, Yersinia ruckeri and Lactococcus garvieae (Sayin et al., 2016). However, no study has evaluated the effects of boric acid on Aeromonas veronii. In this study, the inhibitory activity of boric acid was tested using agar well diffusion method. Inhibition determined based on the diameter of halos (Fig. 1). The results indicated that Photobacterium damselae subsp. damselae and Vibrio species were resistant to boric acid. 
However, boric acid showed an inhibitory effect against Aeromonas veronii with the concentrations of 3.09 and $1.54 \mathrm{mg} / \mathrm{ml}$. Zone diameters were measured as $19.4 \pm 0.5$ $\mathrm{mm}, 15.92 \pm 0.6 \mathrm{~mm}$, respectively.
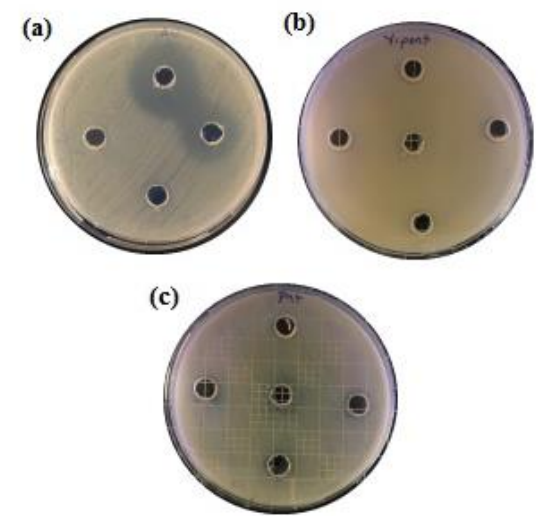

Figure 1. Inhibition zones. (a) Aeromonas veronii, (b) Vibrio ponticus, (c) Photobacterium damselae subsp. damselae

MIC and MBC Determination: The antibacterial effects of drugs are routinely evaluated by agar diffusion and MIC test. The advantage of direct contact tests over agar diffusion method is that they are independent of the diffusion properties of the material and medium under test (Estrela et al., 2001). Therefore, the MIC test is used to determine the lowest concentration of material that will still exhibit antibacterial properties. In this study, after 24 $\mathrm{h}$ of incubation at $24-26^{\circ} \mathrm{C}$ for Aeromonas veronii, turbidity was noticed in the test tubes $0.19,0.38$ and 0.77 $\mathrm{mg} / \mathrm{ml}$ containing boric acid indicating the growth of bacteria. Whereas in concentrations of 3.09 and 1.54 $\mathrm{mg} / \mathrm{ml}$, no turbidity was seen, exhibiting inhibition of bacterial growth. The suspension from the tubes of 3.09 and $1.54 \mathrm{mg} / \mathrm{ml}$ was inoculated on TSA $(+1.5 \% \mathrm{NaCl})$ plates and incubated for $24 \mathrm{~h}$ at $24-26^{\circ} \mathrm{C}$ and no growth of bacteria was observed in both concentrations hence confirming it as bactericidal. These results showed that the $\mathrm{MIC}$ and MBC of boric acid for Aeromonas veronii were found to be effective at concentration of $1.54 \mathrm{mg} / \mathrm{ml}$. The MIC and MBC values of boric acid on bacteria are important, as these values can be used in future research for antibiotic development (Yilmaz, 2012). The MIC and MBC assays illustrated at Figure 2.

Aeromonas spp., including Aeromonas veronii is an important fish pathogen that can be found in the normal micro flora of animals (Smyrli et al., 2017; Uzun \& Ogut 2015). These pathogens cause various infections in humans, such as endocarditis, gastroenteritis, peritonitis, and septicemia (Janda \& Abbott, 2010). They are also primary pathogens in farmed fish (Hossain et al., 2019). A. veronii has been described as an important pathogen of human beings as well as aquatic animals (Cui et al., 2007). Aeromonas species have the capacity to transport and acquire antimicrobial resistance elements, and multi-drug resistant Aeromonas isolates are now widely available worldwide (Tekedar et al., 2020). Therefore, a novel alternative to antimicrobial therapy, boric acid can be recommended for treatment of bacterial infections. Boron containing compounds impair various enzymes including the serine protease family of $\beta$-lactamase (Morandi et al., 2008). Boron is involved in quorum sensing, which is an important mechanism in developing antimicrobial effect (Houlsby et al., 1986; Reichman et al., 2009; Watanabe et al., 1988;). In this study, although some in vitro inhibitory effects of boric acid on Aeromonas veronii were examined, the mechanism of action of the compound on bacteria is not fully elucidated and is the focus of future studies.

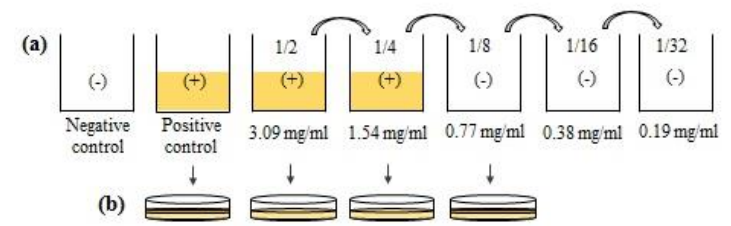

Figure 2. Dilution method for a) the MIC assay and b) the MBC assay.

\section{CONCLUSION}

In aquaculture, the use of new antimicrobial agents as an alternative to antibiotics is of great importance in preventing the development of resistance genes in pathogenic bacteria. The findings in this study, MICs of 3.09 and $1.54 \mathrm{mg} / \mathrm{ml}$ respectively of boric acid has antimicrobial effects against Aeromonas veronii. The results presented here provide evidence that boric acid might serve as a potential antimicrobial agent for Aeromonas veronii in aquaculture, but further experiments are required to evaluate the inhibitory mechanism of boric acid and determine its effect on fish.

\section{REFERENCES}

Akkan, T. \& Çolaker, F. (2020). Determining the bacteriological pollution level of Gelevera Creek, Giresun. J. Anatolian Env. and Anim. Sciences, 5(4), 691-695. DOI: 10.35229/jaes.818132

Akkan, T. \& Topkaraoğlu, T. (2019). Determination of antibiotic resistance levels of Escherichia coli isolates obtained from freshwater sources: Batlama Creek. Journal of Anatolian Environmental and Animal Sciences, 4(3), 539544. DOI: 10.35229/jaes.650210

Balta, F. \& Dengiz Balta, Z. (2016). Vibrio infection and treatment on the juvenile rainbow trout (Oncorhynchus mykiss) transferred seawater. Journal of Anatolian Environmental and Animal Sciences, 1(1), 14-20.

Balta, F. Dengiz Balta, Z. Özgümüş, O.B. \& Çağırgan, H. (2016). The antimicrobial resistance and investigation of Yersinia ruckeri from rainbow 
trout (Oncorhynchus mykiss) farms in the Eastern Black Sea Region. Journal of Anatolian Environmental and Animal Sciences, 1(3), 72-76.

Balta, F. \& Dengiz Balta, Z. (2017). Serotyping, genetic characterization and antimicrobial susceptibility determination of Vibrio anguillarum strains isolated from farmed rainbow trout (Oncorhynchus mykiss) in the eastern Black Sea. Ankara Üniv Vet Fak Derg, 64, 321-328.

Balta, F. \& Dengiz Balta, Z. (2019). The isolation of Lactococcus garvieae from eyes of diseased rainbow trout (Oncorhynchus mykiss) with exopthalmia. Journal of Anatolian Environmental and Animal Sciences, 4(1), 27-33. DOI: 10.35229/jaes.527258

Balta, F. (2020). Determination of the antimicrobial susceptibilities of Aeromonas spp. isolated from rainbow trout farms on the Firtına river. Journal of Anatolian Environmental and Animal Sciences, 5(3), 397-407. DOI: 10.35229/jaes.785447

Cui, H., Hao, S. \& Arous, E. (2007). A distinct cause of necrotizing fasciitis: Aeromonas veronii biovar sobria. Surgical Infections, 8, 523-528. DOI: 10.1089/sur.2006.046

Dinca, L. \& Scorei, R. (2013). Boron in Human Nutrition and its Regulations Use. Journal of Nutritional Therapeutics, 2, 22-29. DOI: 10.6000/19295634.2013.02.01.3

Done, H.Y., Venkatesan, A.K. \& Halden, R.U. (2015). Does the recent growth of aquaculture create antibiotic resistance threats different from those associated with land animal production in agriculture? American Association of Pharmaceutical Scientists Journal, 17, 513-524. DOI: 10.1208/s12248-015-9722-Z

Estrela, C., Rodrigues de Araújo Estrela, C., Bammann, L.L. \& Pecora, J.D. (2001). Two methods to evaluate the antimicrobial action of calcium hydroxide paste. Journal of Endodontics, 27(12), 720-723. DOI: 10.1097/00004770200112000-00002

Goldbach, H.E., Huang, L. \& Wimmer, M.A. (2007). Boron functions in plants and animals: recent advances in boron research and open questions. In: Xu F, Goldbach H, Brown PH, Bell RW, Fujiwara T, Hunt CD, Goldberg S, Shi LF. (Ed). 3-25p Advances in plant and animal boron nutrition. Dordrecht: Springer.

Hatha, M., Vivekanandhan, A.A, Joice, G.J. \& Christol. (2005). Antibiotic resistance pattern of motile aeromonads from farm raised freshwater fish. International Journal of Food Microbiology, 98(2), 131-134. DOI: 10.1016/j.ijfoodmicro.2004.05.017

Hossain, S., Dahanayake, P.S., De Silva, B.C.J., Wickramanayake, M.V.K.S., Wimalasena,
S.H.M.P. \& Heo, G.J. (2019). Multi-drug resistant Aeromonas spp. isolated from zebrafish (Danio rerio): antibiogram, antimicrobial resistance genes and class 1 integron gene cassettes. Letters in Applied Microbiology, 68, 370-377. DOI: 10.1111/lam.13138

Houlsby, R.D., Ghajar, M. \& Chavez, G.O. (1986). Antimicrobial activity of borate-buffered solutions. Antimicrobial Agents and Chemotherapy, 29, 803-806. DOI: 10.1128/aac.29.5.803

Janda, J.M. \& Abbott S.L. (2010). The genus Aeromonas: taxonomy, pathogenicity, and infection. Clinical Microbiology Reviews, 23, 3573. DOI: 10.1128/CMR.00039-09

Morandi, S., Morandi, F., Caselli, E., Shoichet, B.K. \& Prati, F. (2008). Structure-based optimization of cephalothin-analogue boronic acids as betalactamase inhibitors. Bioorganic \& Medicinal Chemistry, 16, 1195-1205. DOI: 10.1016/j.bmc.2007.10.075

Nielsen, F.H. (1997). Boron in human and animal nutrition. Plant and Soil, 193, 199-208.

Öz, M., Inanan, B.E. \& Dikel, S. (2018). Effect of boric acid in rainbow trout (Oncorhynchus mykiss) growth performance. Journal of Applied Animal Research, 46(1), 990-993. DOI: 10.1080/09712119.2018.1450258

Perez, C., Paul, M. \& Bazerque, P. (1990). An antibiotic assay by the agar well diffusion method. Acta Biologiae Et Medicinae Experimentalis, 15, 113115.

Reichman, O., Akins, R. \& Sobel, J.D. (2009). Boric acid addition to suppressive antimicrobial therapy for recurrent bacterial vaginosis. Sexually Transmitted Diseases, 36(11), 732-734. DOI: 10.1097/OLQ.0b013e3181b08456

Resende, J.A., Silva, V.L., Fontes, C.O., Souza-Filho, J.A., Rocha de Oliveira, T.L., Coelho, C.M., César, D.E., \& Diniz, C.G. (2012). Multidrugresistance and toxic metal tolerance of medically important bacteria isolated from an aquaculture system. Microbes Environments, 27, 449-455. DOI: 10.1264/jsme2.me12049

Russel, J.B. \& Diez-Gonzalez, F. (1998). The effects of fermentation acids on bacterial growth. Advances in Bacterial Physiology, 39, 205-234. DOI: 10.1016/s0065-2911(08)60017-x

Samman, S., Naghii, M.R., Lyons Wall, P.M. \& Verus, A.P. (1998). The nutritional and metabolic effects of boron in humans and animals. Biological Trace Element Research, 66, 227-235. DOI: 10.1007/BF02783140 
Sayin, Z., Ucan, U.S. \& Sakmanoglu, A. (2016). Antibacterial and Antibiofilm Effects of Boron on Different Bacteria. Biological Trace Element Research, 173, 241-246. DOI: 10.1007/s12011016-0637-z

Smyrli, M., Prapas, A., Rigos, G., Kokkari, C., Pavlidis, M. \& Katharios, P. (2017). Aeromonas veronii infection associated with high morbidity and mortality in farmed European seabass Dicentrarchus labrax in the Aegean Sea, Greece. Fish Pathology, 52, 68-81. DOI: 10.3147/JSFP.52.68

Tekedar, H.C., Arick, M.A., Hsu, C.Y., Thrash, A., Blom, J., Lawrence, M. L. \& Abdelhamed, H. (2020). Identification of Antimicrobial Resistance Determinants in Aeromonas veronii Strain MS17-88 Recovered From Channel Catfish (Ictalurus punctatus). Frontiers in Cellular and Infection Microbiology, 10, 348. DOI: 10.3389/fcimb.2020.00348

Topal, A., Oruç, E., Altun, S., Ceyhun, S.B. \& Atamanalp, M. (2016). The effects of acute boric acid treatment on gill, kidney and muscle tissues in juvenile rainbow trout. Journal of Applied Animal Research, 44(1), 297-302. DOI: 10.1080/09712119.2015.1031784

Uzun, E. \& Ogut, H. (2015). The Isolation Frequency of Bacterial Pathogens from Sea Bass (Dicentrarchus labrax) in the Southeastern Black Sea. Aquaculture. 437, 30-37. DOI: 10.1016/j.aquaculture.2014.11.017

Uzun-Yaylacı, E. (2019). Developing a differentiation technique for the pathogenic bacteria causing disease in sea bass (Dicentrarchus labrax) by using artificial neural networks. Doctoral thesis, Karadeniz Technical University, The Graduate School of Natural and Applied Sciences, Trabzon, Turkey, 49-50p.

Watanabe, S., Fujita, T. \& Sakamoto, M. (1988). Antimicrobial properties of boric acid esters of alcohols. Journal of the American Oil Chemists' Society, $\quad 65, \quad 1479-1482 . \quad$ DOI: 10.1007/BF02898312

Yang, F., Zhu, M., Zhang, J. \& Zhou, H. (2018). Synthesis of biologically active boron-containing compounds. Medicinal Chemistry Communications, 9, 201-211. DOI: $10.1039 / \mathrm{c} 7 \mathrm{md} 00552 \mathrm{k}$

Yılmaz, M.T. (2012). Minimum inhibitory and minimum bactericidal concentrations of boron compounds against several bacterial strains. Turkish Journal of Medical Sciences, 42,1423-1429. DOI: 10.3906/sag-1205-83 